大であるが，窒化物生成ととるにこれが抵抗となり窒化 速度定数は時間之共に低下する。

（iii）窒化過程の粒子が溶融焼結しない窒化条件範囲

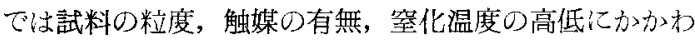
らず窒化反応は反応初期は拡散，それ以降は搪散点含志 化学反応が支配的である。粒子狫結の場合惊搪散支配と なる。

（iv） 窒化反応速度はカーバイド粒子存焼絬させない で窒化する場合従来報告されている数值の数分の1の低 い值である．流動窒化法にわわては流動層队の石灰空素 濃度により咥化速度は著しく変化する。

（v）活性化エネルギは静止窒化法の場合 $50 \mathrm{kcal} / \mathrm{mol}$ であるが，振動法および流動窒化中間品の熟成窒化法に おいては静止法の 1/2 1/3 の数值であり, 流動法にお いては流動首内の石灰窑素濃度に上り変化する。

流動工学，流動窒化化つては東京大学矢木教授，国 井助教授ので想篤なるで指導を得た。，厚くお礼申し、ヒげ
る.

この研究を終始激励援助し，乙の報文の公表花許可さ れた信越化学工業株式会社小坂德三郎社長に深謝申し上 げる.

(昭 $36-4-3$ 受理)

\section{文 献}

1) 领村雄二, 中島恒雄, 三宫芳助, 本誌 29，317 (1961).

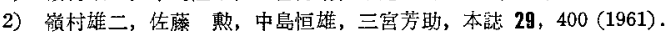

3）蓣村雄二，中島恒雄，三宫芳助，本誌 29，486 (1961).

4) 嶺村雄二, 白川洪象, 坂井正親, 本誌 29, 581 (1961).

5）嶺村雄二，佐藤 勲，生駒正信，上条能油，本誌 29，627 (1961).

6) G. Bredig, W. Fraenkel, E. Wilke, Z. Elektrochem. 13, $605(1907)$.

7) H. H. Franck, F. Hockwald, Z. Electrochem. U. Ange. Physik. Chem. 3111 (1925).

8) T. Aono, Bull. Chem. Soc. Japan. 8, 274 (1932).

9) H.H. Franck, Harry Endler, Z. Physik. Chem. 184, 127 (1937).

10) T. Aono, Bull. Chem. Soc. Japan. 1, 247 (1932); 16, 97 (1941).

\title{
燃料電池（II） 焼結ニッケル電極の前酸化処理について*
}

\section{Fuel Cell (II) On the Pre-oxidation of the Sintered Nickel Electrode}

\section{1. 緒言}

$\mathrm{H}_{2}-\mathrm{O}_{2}$ 燃料電池のガス電極としては主として多孔性炭 素電極または多孔性焼結 $\mathrm{Ni}$ 電極か使用されている。焼 結 $\mathrm{Ni}$ 電極は炭素電極汇比較して機珹的強度が強く，ま た比較的高温に耐えるととができるなどの点ですぐれて いる.したがって 200〜 300 $\mathrm{C}$ の高温でしかる高压の $\mathrm{H}_{2}, \mathrm{O}_{2}$ を使用するととができ，電極の単位面積（見掛） 当りの出力を増大するととができる，たとえば二重多孔 性 $\mathrm{Ni}$ 電極を使用したいわりる Bacon Cell では，作動 温度 $240^{\circ} \mathrm{C}, \mathrm{H}_{2}$ および $\mathrm{O}_{2}$ の圧力 $54 \mathrm{~atm} の$ とき，端子 電圧 $0.8 \mathrm{~V}$ で $600 \mathrm{~mA} / \mathrm{cm}^{2}$ の電流密度が得られてい

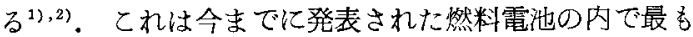
すぐれたものの1つである。この Bacon Cell の酸素極 側汸いては，焼結 $\mathrm{Ni}$ 電極を使用してもなお酸化窗食 され，乙か子比較的高抵抗の緑色 $\mathrm{NiO}$ 在生成し十数時 間で使用不能となる。この酸化腐食を防ぐ方法としてケ 酸カりまたはアルミン酸カリなぞの添加も試みられ， ある程度防食のあることがわかったが，電極反応に目の 影響を与えるので実際の然料電池に使用するに法好まし

\footnotetext{
* 昭和 36 年 4 月 3 日 日本化学会第 14 年会にて講演
}

**名古屋大学工学部応用化学教室 (名古屋市千種区不老町)
高橋 武 彦**, 伊藤 要**

Takehiko TAKahashi Kaname IтO

くない2)。したがってあらかじめ高温で $\mathrm{Ni}$ を空気酸化 して金属 Ni 表面任酸化薄膜を生成させて窝食を防ぐし とが考元られた，その際生成する酸化膜は導電性の上小 まのでなくてはならないから Bacon は $\mathrm{Li}^{+}$の存在の下 であらかじめ前酸化处理を行ない，きわわて導電性のよ いニッケル酸化物半導体(ニッケルとリチウムの酸化物 固溶体で, $\mathrm{Ni}(\mathrm{Li})$ 酸化膜と記す)生成させて, これを $\mathrm{O}_{2}$ 電極して使用した．著者らはての前酸化処理につい て詳細な知見在得る為江金属 $\mathrm{Ni}$ 板を試料として種々の 条件で前酸化処理を行ない，Ni(Li) 酸化膜の生成状況， および $\mathrm{Li}^{+}$の挙動について検討し，てれらが生成酸化 薄膜の電気抵抗に及ぼ影響拉よび $\mathrm{O}_{2}$ 極としての分極 特性に及ぼ寺影響について検討した。

\section{2. 実験および結果}

\section{1 試 料}

$\mathrm{Ni}$ 板試料は厚さ $0.5 \mathrm{~mm}$ のタンザク形 $\left(10 \times 1 \mathrm{~cm}^{2}\right)$ の純 $\mathrm{Ni}$ 板空使用し，下記のような条件で前酸化処理を 行なった。前酸化処理に 先だち $\mathrm{Ni}$ 板試料を熱濃 $\mathrm{HCl}$ にて $3 \mathrm{~min}$ 間処理して, 表面状㦔の均一化在計った。

\section{$2.2 \mathrm{Ni}(\mathrm{Li})$ 酸化膜の生成}

2.2.1 前酸化処理条件 $\mathrm{Li}^{+}$の添加用試薬としては 
市販の最純 $\mathrm{LiOH}$ を使用した. $\mathrm{NiO}$ から $\mathrm{NiO}$ と $\mathrm{LiO}$ の固溶体を作る祭には多くの場合 $\mathrm{Li}_{2} \mathrm{CO}_{3}$ 方使用されて いるか ${ }^{33)}, \mathrm{Li}_{2} \mathrm{CO}_{3}$ の溶解度は $1.33 \mathrm{~g} / 100 \mathrm{~g}$ 水 $\left(210^{\circ} \mathrm{C}\right)$ で 小さく， $\mathrm{Li}^{+}$の各檑濃度の溶夜をつくるに湔不適当であ るので $\mathrm{LiOH}$ を採用し，1\%，5\%，10\% の水溶液在作 った．とれらの溶液に武料 $\mathrm{Ni}$ 板を浸せきし $120^{\circ} \mathrm{C}$ で乾 燥後, 所定の温度 $\left(600,700,800^{\circ} \mathrm{C}\right)$ にて $1 \mathrm{~h}$ 空気中で 加熱酸化した. 加熱後試料を炣外に取出して急冷し, 冷 却後 $\mathrm{LiOH}$ を除去するたり $2 N$ 醋酸に浸せきし，蒸留 水で十分に洗浄した，希醋酸溶液仙よって，未反応の $\mathrm{LiOH}$ および空気中の $\mathrm{CO}_{2}$ 上反応して生成した $\mathrm{Li}_{2} \mathrm{CO}^{3}$ は溶解除去されるが, $\mathrm{Ni}(\mathrm{Li})$ 酸化物哇溶解されれないう で, $\mathrm{Ni}(\mathrm{Li})$ 酸化膜中に入って固溶体を生成した $\mathrm{Li}^{+}$は そのまま酸化物中に残存する。

2.2.2 $\mathrm{Li}^{+}$の分析 生成した $\mathrm{Ni}(\mathrm{Li})$ 酸化膜中の $\mathrm{Li}^{+}$は炎光光度法により 定量した ${ }^{5} . \mathrm{Li}^{+}$の標準試菒と しては再沈殿法6)によって精製した $\mathrm{Li}_{2} \mathrm{CO}_{3}$ を使用し先 ず 2,000 ppm Li+ 標準溶波を調製した。次いで $\mathrm{Li}^{+}$の 発光に刘する $\mathrm{Ni}^{2+}$ の妨害作用はあまり大ではない5 が 念のため $\mathrm{Ni}^{2+} 500 \mathrm{ppm}$ (試料溶液を調製する際 $\mathrm{Ni}^{2+}$ は 常汇約 $500 \mathrm{ppm}$ となるように, Ni 板試料の溶解時間を 予備実験から定めた）を共存させた状態での $\mathrm{Li}^{+} 0 \sim 20$ $\mathrm{ppm}$ 製作の检量線をし，乙れを基準にして次のような 操作倸占 $\mathrm{Li}^{+}$の定量在行なった。な枋容器から溶出す る $\mathrm{K}^{+}, \mathrm{Na}^{+}$の影響を除くためにポリエチレン製の武薬 ビンおよびビーカーを使用し，ポりエチレンの使用でき ない蒸発乾固の操作ではあらかじめ濃 $\mathrm{HCl}$ で煮沸した 硬睤ビーカーを使用した。

前酸化处理後末反応の $\mathrm{Li}^{+}$完全に除去した $\mathrm{Ni}$ 板試 料 $\left(10 \times 1 \mathrm{~cm}^{2}\right)$ を先ず試薬特級の濃 $\mathrm{HCl} 10 \mathrm{cc}$ 中に入 れて 3 6 min 間加熱し, 酸化膜を溶解した。ほとんど 酸化膜が溶解し終ったところで金属 $\mathrm{Ni}$ 板を取出し，溶 液のみをさらに加熱してはとんど苲発乾固の状態にし， 余分の $\mathrm{HCl}$ を除去した。冷却後水を少量加光てメスフ ラスコに移し $100 \mathrm{~m} l$ または $50 \mathrm{~m} l$ とし,てれを武料溶 液として炎光光度分析䒾置により $\mathrm{Li}^{+}$の発光強度を測定 L，先行得た検量線加ら $\mathrm{Li}^{+}$の含量を求めた。

2.2.3 Ni(Li) 酸化膜の生成量について $\mathrm{NiO}$ と $\mathrm{Li}_{2} \mathrm{CO}_{3}$ を混合して，酸化性の雾囲気中で高温（800〜 1, $200^{\circ} \mathrm{C}$ ) で焼結すると $\mathrm{Li}^{+}$は $\mathrm{NiO}$ の結晶中の $\mathrm{Ni}^{2+}$ の格子点を置換し，NiO-LiO の固溶体老生成する。 そ の際電気的中性を保つために格子点を置換した $\mathrm{Li}^{+}$と当 量の $\mathrm{Ni}^{2+}$ が $\mathrm{Ni}^{3+}$ になる。したがってててに生成した 固溶体沈次のような化学式で表わされる7).

$$
\mathrm{Li}_{x} \mathrm{Ni}^{2+}{ }_{(1-2 x)} \mathrm{Ni}^{3+}{ }_{(x)} \mathrm{O}
$$

金属 $\mathrm{Ni}$ 加出発した本実験においても前酸化処理に よって生成した $\mathrm{Ni}(\mathrm{Li})$ 酸化膜は，(1) 式と同様の化学 式で表わされる組成を有しているであらう，今前酸化処
理の前後における重量增加を $a_{g}$ とし, 生成酸化膜中の $\mathrm{Li}^{+}$の量を $b_{g}$ とすると, 生成した $\mathrm{Ni}(\mathrm{Li})$ 酸化膜の生 成量 $(\mathrm{Mg})$ は炏のようになる。

$$
\begin{aligned}
\mathrm{M} & =\left(\frac{\mathrm{O}+\mathrm{Ni}}{\mathrm{O}}\right) a-\left[\frac{(\mathrm{Li}+\mathrm{O}) \mathrm{Ni}}{\mathrm{Li} \times \mathrm{O}}\right] b \\
& =4.66 a-1.21 b
\end{aligned}
$$

（2）式索使用して，各条件での前酸化処理前後の重量 堌加の実測值と $\mathrm{Li}^{+}$の分析結果加ら, $\mathrm{Ni}(\mathrm{Li})$ 酸化膜の 生成量を計算した。 図 1 は, 前酸化処理の際の浸せき用 $\mathrm{LiOH}$ の濃度と単位面積当りの $\mathrm{Ni}(\mathrm{Li})$ 酸化膜の生成量 との関係を示したものである・また図2 は図 $10 \mathrm{Ni}(\mathrm{Li})$. 酸化膜の生成量を加熱温度に対して示したものである。

これらの図から明らかなように前酸化処理の際の浸せ き用 $\mathrm{LiOH}$ の濃度が $5 \%$ までは, 前酸化処理によって 金属 $\mathrm{Ni}$ 板上に生成する $\mathrm{Ni}(\mathrm{Li})$ 酸化膜は加熱温度には 大体依存し， $600^{\circ} \mathrm{C}$ 加ら $800^{\circ} \mathrm{C}$ へと高温になるほど多 くなっている。しかもその生成量は $\mathrm{LiOH}$ 無添加の場

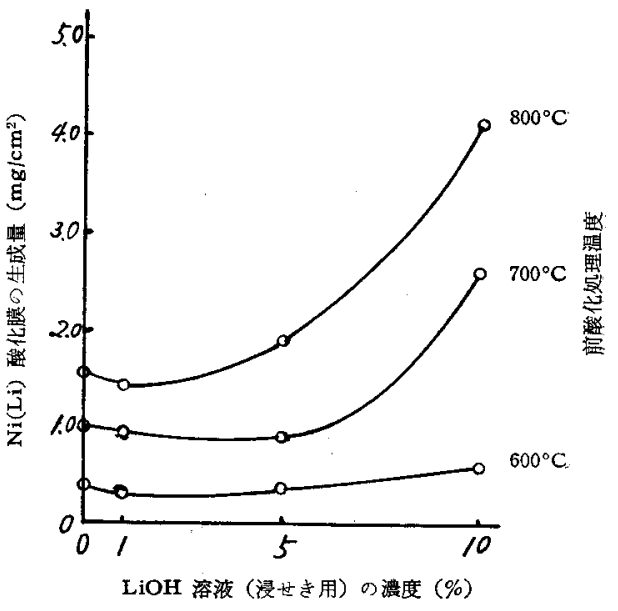

困 $1 \mathrm{Ni}$ 板上の $\mathrm{Ni}(\mathrm{Li})$ 酸化膜の生成量

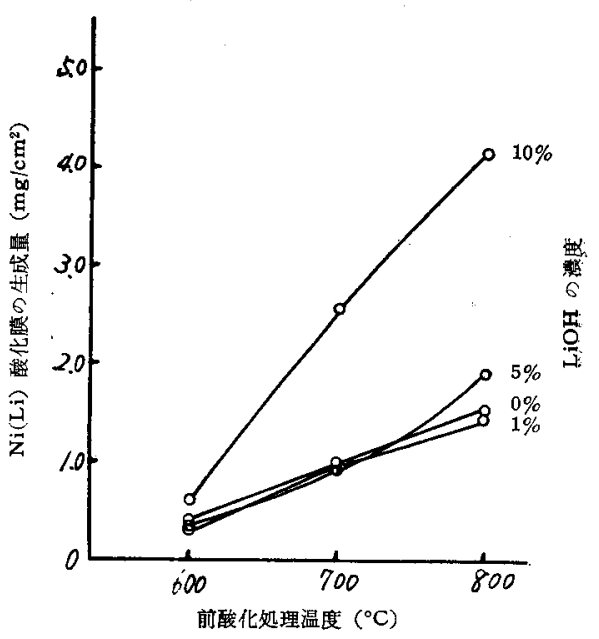

因 $2 \mathrm{Ni}$ 板上の $\mathrm{Ni}(\mathrm{Li})$ 酸化膜生成量 
合とほとんど同じである。しかるに 10\% LiOH 溶液に 浸せきした場合のように， $\mathrm{Li}^{+}$の多量の存在のもとでの 加熱酸化では $\mathrm{Ni}(\mathrm{Li})$ 酸化膜の生成量が力なり增大し, $700,800^{\circ} \mathrm{C}$ では $2.6,4.1 \mathrm{mg} / \mathrm{cm}^{2}$ となった。 しか子生 成した $\mathrm{Ni}(\mathrm{Li})$ 酸化膜は，はく脱しやすく表面状態山粗 雑になった。したがっててのような㚾理条件を焼結 Ni 電極に適用すれば，機械的強度を低下するので好ましく ないであろう。

\subsection{4 $\mathrm{Ni}(\mathrm{Li})$ 酸化膜中の $\mathrm{Li}^{+}$含有量について}

$\mathrm{LiOH}$ 溶液侵せきするととなく $\mathrm{Ni}$ 板のみを 600〜 $800^{\circ} \mathrm{C}$ の高温に空気中で加熱した場合，Ni 板の表面に は緑色か珈った $\mathrm{NiO}$ 膜を生成する。しかるに $\mathrm{Li}^{+}$の存 在のもとで加熱した場合には一様に黒色 $\mathrm{Ni}$ 酸化膜を生 成する。乙れは前述したように $\mathrm{Ni}$ と $\mathrm{Li}$ の酸化物固溶 体生成したためで，乙の固溶体中の $\mathrm{Li}^{+}$の含有量は 生成 $\mathrm{Ni}(\mathrm{Li})$ 酸化膜の性質学規定する因子になるものと 考壳られる。したがってその存在状態ら明らかれするこ

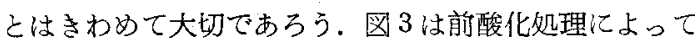
生成した $\mathrm{Ni}(\mathrm{Li})$ 酸化膜中の $\mathrm{Li}^{+}$含有量在測定した結 果であり，図 4 はその生成酸化膜中の $\mathrm{Li}^{+}$含有率を示し たものである。すなわち著者らの実験範国内では，浸せ き用 $\mathrm{LiOH}$ 溶液の濃度が高くなればなるほぼ，また加 熱温度が高くなればなるほぼ， $\mathrm{Li}^{+}$○含有量は多くなっ ている.しかし $\mathrm{Ni}(\mathrm{Li})$ 酸化膜の生成量もての上うな傾 向にあるので $\mathrm{Li}^{+}$の含有率は図 4 亿示すように浸せき用 $\mathrm{LiOH}$ 溶液の濃度，すな⿰力口古加熱酸化時の $\mathrm{Li}^{+}$の存在 量に依存し加熱温度による影響は少ない。

\section{$2.3 \mathrm{Ni}(\mathbf{L} \mathbf{i})$ 酸化膜の抵抗}

2.3.1 抵抗の測定方法 $\mathrm{Ni}$ 板上に生成した $\mathrm{Ni}(\mathrm{Li})$ 酸化膜の抵抗は同一武料であってる測定場所によってき わめて異なった值を示し，特に $600^{\circ} \mathrm{C} の$ 加熱で生成した きわわて薄い膜の場合にはその再現性が烈い．したがっ て比抵抗の正確な值意求めることは因難であるが，前酸

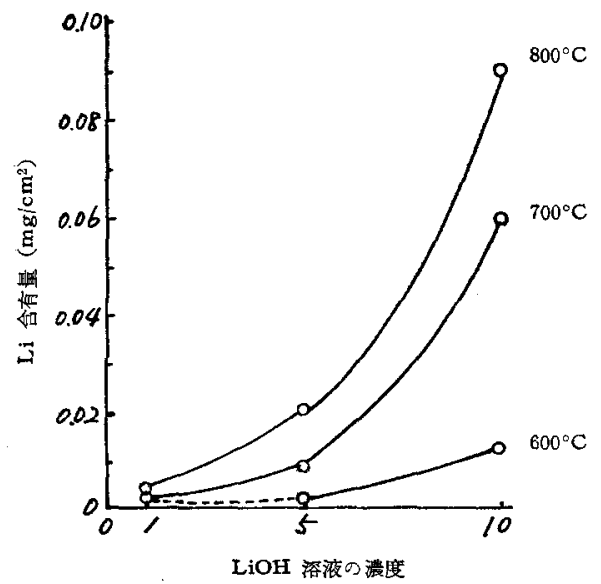

図 3 生成 $\mathrm{Ni}(\mathrm{Li})$ 酸化膜中の $\mathrm{Li}$ 含有量

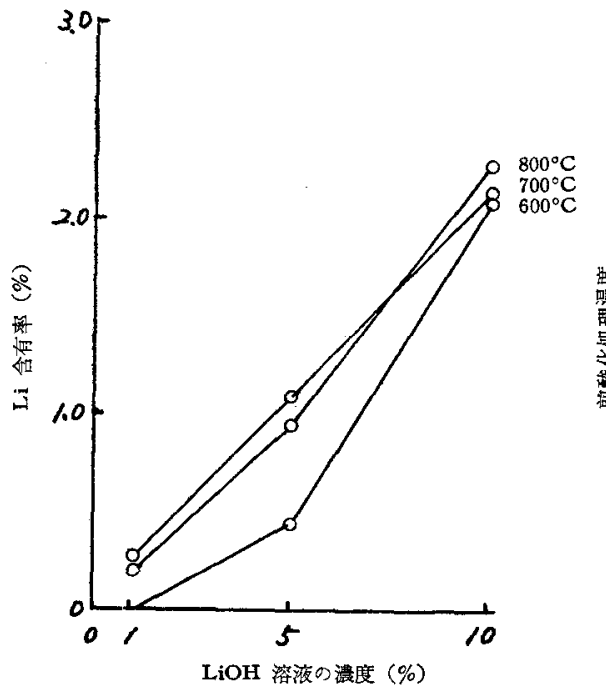

図 $4 \mathrm{Ni}(\mathrm{Li})$ 酸化膜中の $\mathrm{Li}$ 含有率 化処理条件の差基く抵抗の変化仿かなり大きいので, 抵抗の比較值として次のような方法によって室温沈引け

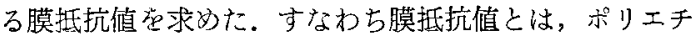
レン棒の表面にはりつけた $\mathrm{Al}$ 䇴電極 $\left(0.5 \times 0.5 \mathrm{~cm}^{2}\right)$ を試料の上亿のせ約 $2 \mathrm{~kg} / \mathrm{cm}^{2}$ の圧力を加えたときの， $\mathrm{Ni}$ 基板との間の抵抗をテスターで測定したものであり， 数回位置を变えて测定した值の平均を図 5 亿示した。

2.3.2 抵抗の測定結果について 酸化ニッケルを酸

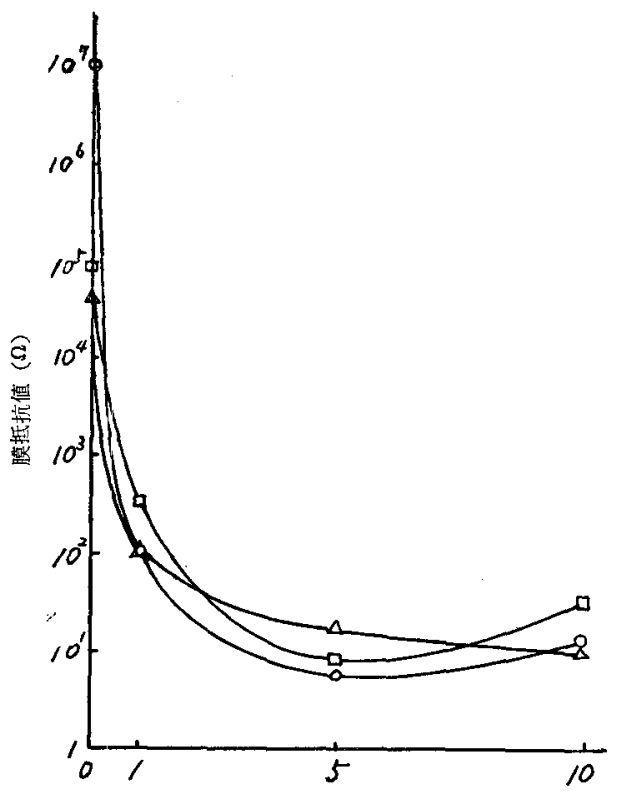

$\mathrm{LiOH}$ 浴液の瀑度 $(\%)$

前酸化処理温度： $\bigcirc 800^{\circ} \mathrm{C} \square 700^{\circ} \mathrm{C} \triangle 600^{\circ} \mathrm{C}$ 测定温度 : 室温

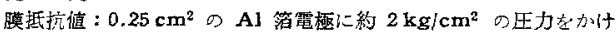
たとさの $\mathrm{Ni}$ 板との間の抵抗值

四 $5 \mathrm{Ni}$ 板上に生成した $\mathrm{Ni}(\mathrm{Li})$ 酸化膜 
化性のふんい気中で $1,200^{\circ} \mathrm{C}$ に焼成したと省に生成する 純酸化ニッケルの比抵抗はきわめて高 $1<0^{8} \Omega \mathrm{cm}$ であ るが, $\mathrm{Li}_{2} \mathrm{CO}_{3}$ の存在のもとに加熱した場合にはをの抵 抗は急激に小さくなる. Verwayらわの結果によれ ば $\mathrm{Li}^{+}$含有率 $0.2 \%$ でその比抵抗は $10^{2} \Omega \mathrm{cm}, 1 \%$ で $12 \Omega \mathrm{cm}, 2 \%$ で $7 \Omega \mathrm{cm}$ である.

本実験においては金属 $\mathrm{Ni}$ から出発しているか：各条件 での前酸化処理によって得られた $\mathrm{Ni}(\mathrm{Li})$ 酸化膜の抵抗 の比較值（膜抵抗值，図5) から明らかなように $\mathrm{Li}^{+} の$ 存在しない状態で生成した $\mathrm{Ni}$ 酸化膜は，膜抵抗值とし て $10^{5} \sim 10^{7} \Omega$ と，加方高小值を得た。それに刘して $\mathrm{Li}^{+}$がかずかと入った場合（たと元ば $19 \% \mathrm{LiOH}$ 溶液 に浸せきした場合，すなわち Li 合有率が $0 \sim 0.25 \%$ ) でも膜抵抗值は急激に小さくなり $\left(10^{2} \sim 3 \times 10^{2} \Omega\right)$, 本実 験の酸化温度範囲では浸せき用 $\mathrm{LiOH}$ 溶液の同一濃度 に対してほとんど同じ膜抵抗值を得た。

図 4 から $\mathrm{Ni}(\mathrm{Li})$ 酸化膜中の $\mathrm{Li}^{+}$○含有莩仗，浸せき 用 $\mathrm{LiOH}$ の濃度に大体比例するものと考元られる。し たがって図 5 の膜抵抗值は $\mathrm{Ni}(\mathrm{Li})$ 酸化膜中の Li 含有 率によって規定されるものと考光てよいであるう。その 傾向はVerway らによって得られた $\mathrm{Ni}(\mathrm{Li})$ 酸化物固溶 体の抵抗の結果 ${ }^{7}$ 乙同し傾向を示している。

以上の結果から浸せき用 $\mathrm{LiOH}$ 溶液としては，5１0 900 濃度のものを使用すれば十分に小さな抵抗を有する $\mathrm{Ni}(\mathrm{Li})$ 酸化膜を生成しうるものと考えられる。

\section{4 分 極特性}

2.4.1 分極特性の測定 $\mathrm{Ni}$ 電極を前酸化処理した 場公，その処理条件か燃料電池としての作動特性に及ば す影響虏㛟討するために前述のような前酸化処理法によ り調製した $\mathrm{Ni}$ 板 $\left(1 \times 5 \times 0.05 \mathrm{~cm}^{3}\right)$ 在電極として, 高 温 $\left(200^{\circ} \mathrm{C}\right)$ ，常圧の条件下で酸素ガス電極としての分極 特性を測定した。すなわち Bacon Cellのような高温高

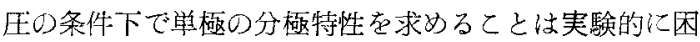
難であるので, $\mathrm{KOH}$ の濃厚溶液 $\left(\mathrm{KOH}: \mathrm{H}_{2} \mathrm{O}=30\right.$ : 10)在電解液とし, $\mathrm{O}_{2}$ ガス压 $1 \mathrm{~atm}$, 作動温度 $200^{\circ} \mathrm{C}$ の条件で実験した，実験装置の概略は図 6 亿示すように 補助電極としては銀板を緗く切名開いた $\mathrm{O}_{2}$ ガス電極 $\left[\mathrm{O}_{2}(\mathrm{Ag})\right.$ 電極 $]$ を使用した。

本実験の測定結果はこの電極の電位を基準にして表示 した*.

2.4.2 測定結果について 本実験で使用した $\mathrm{Ni}$ 板 電極が $\mathrm{O}_{2}$ ガス電極として作動しているか否が検討す るために，電極への流通ガスを $\mathrm{O}_{2}$ または $\mathrm{N}_{2}$ とし， $0.2 \mathrm{~mA} /$ electrode 電流を流したときの電位一時間曲線

* この $\mathrm{O}_{2}(\mathrm{Ag})$ 電㥛の電位は予䚚実験に上れは再現性む上く，分極む

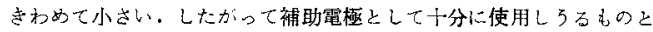
考えられる、しかしなからこの電極の電位は必ずしい酸素の平衡電位 老示しているとは断定できないただ，安定な電位を示す補助電極と して使用した。

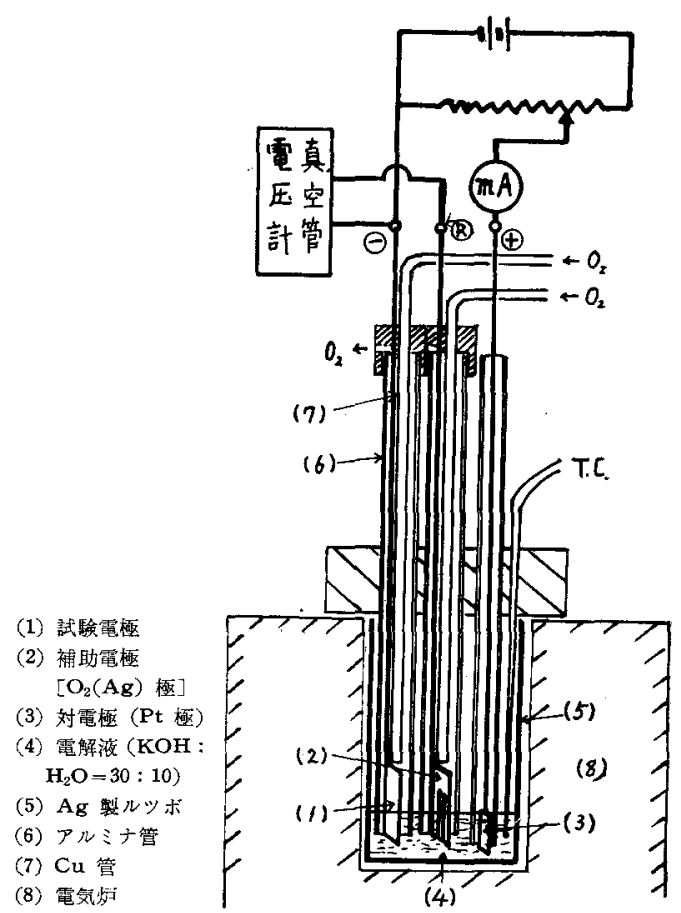

図 6 分極特性測定装置

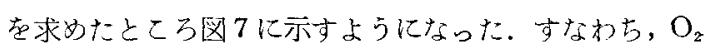
ガスを流通させたときには2〜50 $\mathrm{mV}$ の分柾を示し，ほ とんど経時変化を譛めなかった。一方 $\mathrm{N}_{2}$ ガスを流通し た時には $400 \sim 1,000 \mathrm{mV}$ の分棳を示し経時変化を認內 た。これは明らかに $\mathrm{O}_{2}$ ふんい気では $\mathrm{O}_{2}$ ガス電㮴とし て作勤しているために分極がきわめて小さいが， $\mathrm{N}_{2}$ ふ んい気では Ni 酸化物電極として作動しているために分 極が大きく，また特間的にいつまでも変化したものと考 えられる。ただしての図に㧤いて前酸化処理を行なおな

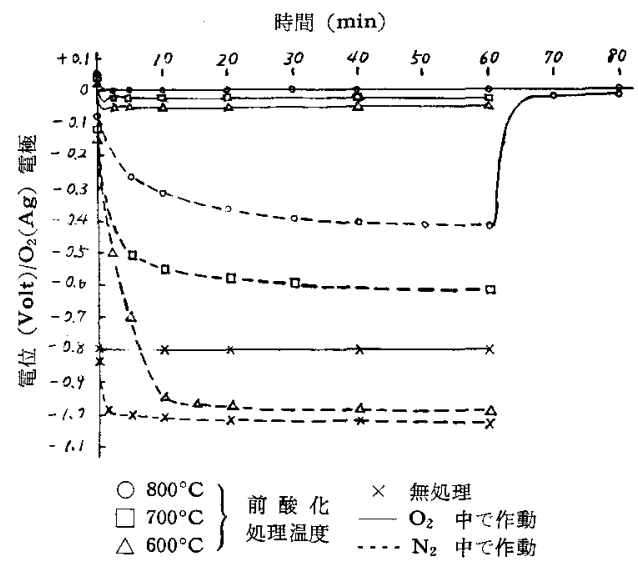

板電極の大きき: $5 \times 1 \mathrm{~cm}^{2}$, 電解液; $\mathrm{KOH}: \mathrm{H}_{2} \mathrm{O}=30: 10$, 電流;

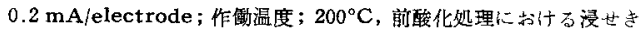
用 $\mathrm{LiOH}$ 溶液の浱度 $10 \%$

図 7 前酸化処理した $\mathrm{Ni}$ 板電極の分極 $\left(\mathrm{O}_{2}\right.$ 極として) の経時変化 


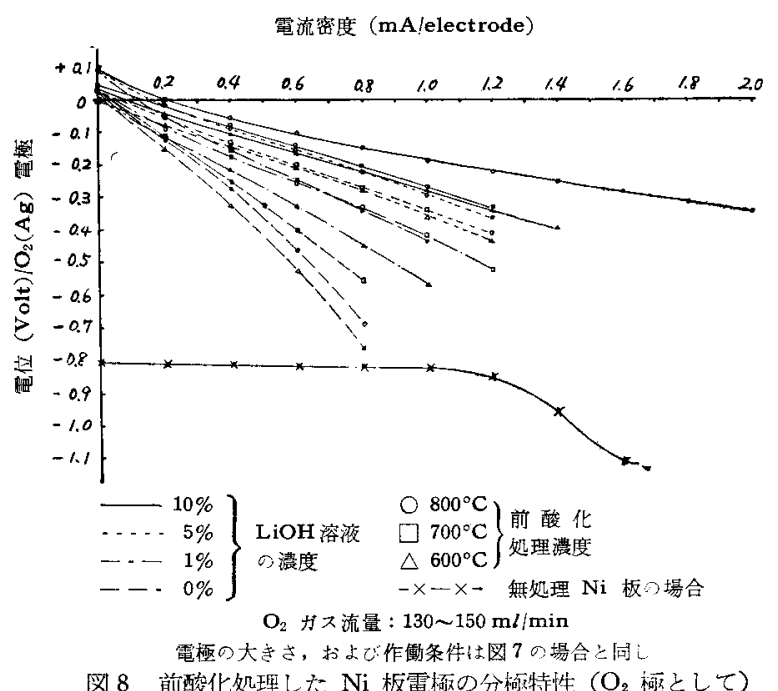

かった金属 $\mathrm{Ni}$ 板では初めから雪位か低く， $-0.8 \mathrm{~V} の$ 值を示しこの点で，ガス電極として働いているようであ る。すなわち $\mathrm{N}_{2}$ 中では通電後間もなく $-1.0 \mathrm{~V}$ と, 水素の発生電位になる。 また金属 $\mathrm{Ni}$ 板の $\mathrm{O}_{2}$ ガス電極 としての分極特性は図 8 亿示すようになった。このよう に金属 $\mathrm{Ni}$ 板をそのまま $\mathrm{O}_{2}$ ガス電極として作動させた 場合, $\mathrm{O}_{2}(\mathrm{Ag})$ 電極電位に対して $-0.8 \mathrm{~V}$ の電位降下者 示すのは $\mathrm{O}_{2}$ の级着化伴うエネル゙損失と考元られる が,との点を明確にするにはなお，今後の检討在必要と する.

前記条件により前酸化処理した $\mathrm{Ni}$ 板学電栈としたと きの $\mathrm{O}_{2}$ 電極としての分極特性は図 8 亿示すようになっ た。すなわち前酸化処理するてとにより金属 Niにおけ るような $\mathrm{O}_{2}$ の财着エネルギ損失に基く電位降下もなく， $\mathrm{O}_{2}$ ガス電極としてかなりよく㗢いているととがわかる。 しかし Ni 酸化物の生成条件梳，その分極特性に影響す る.すなわち $\mathrm{Li}^{+}$を全く加えないで処理した抵抗の高い $\mathrm{Ni}$ 酸化膜を有する電極では分極特性も悪いか;, $\mathrm{Li}^{+}$の 存在のもとで前酸化処理した導電性の $\mathrm{Ni}(\mathrm{Li})$ 酸化膜卒 有する電極ではかなりよい分極特性を示すようになり， $\mathrm{LiOH}$ の濃度が高いはど，また処理温度が高い任ど，分 極は少なくはっている。

一般に電極反応に拈りる分極は活性化分極，濃度分極 わよび抵抗による分極办らなっている。しの内濃度分極 は濃 $\mathrm{KOH}$ の電解液, 温度 $200^{\circ} \mathrm{C}$ という作動条件およ び電極の構造などから考学て本実験のような電流密度の 小さい範用では，きわめて小さく無視しうるものと考え られる．また多少濃度分極が影響してきたとしても電極 の構造および作動条件が同じであるので，同一電流密度 に対しては等しく影響してくるものと考光られる。した がって図 8 の分極特性の差は主として活性化分極および
抵抗による分極に基くものであろう。

抵抗汇よる分極の内, 電解酷の抵抗に基く分極 (IR drope) は, 電解液の抵抗 $(R)$ 䖞きわ好て小さ く，また測定電流 $(I)$ まわわて小さいので，ほと んど無視できるものと考えられる。しかし $\mathrm{Ni}$ 電極 の表面に生成した $\mathrm{Ni}(\mathrm{Li})$ 酸化膜の抵抗は無視でき ないであらう。すなわち膜抵抗值として図 5 に示し たように $\mathrm{Li}^{+}$無添加の場合は $\mathrm{Li}^{+}$分分に添加した 場台と比較して常温で $10^{6}$ 倍の抵抗である。こ饥ら の酸化膜は半導体であるから高温になれば抵抗值は 小さくなり，またこれらの温度係数》加ら考元てそ の差も小さくなる傾向山あるか，それ学無視するて とはできないであろう。したがって $\mathrm{Ni}(\mathrm{Li})$ 酸化膜 の抵抗が分極の支配的因子となっているものとす机 ばその抵抗か小さいはど，すなわち $\mathrm{LiOH} の$ の漂度 か高いほど，小さい分極で作動するものと考元られ

る.しかし同じ濃度の $\mathrm{LiOH}$ で前酸化処理した電 極でも処理温度が高い活ど，小さい分極を示すがこれは 処理温度が高いほど, $\mathrm{Ni}(\mathrm{Li})$ 酸化膜の生成量が多くそ れによる電極表面の物理的形状の変化による活性化分極 の減少によるものと考光られる。しかし，いずれの因子 がての場合の分極を起す支配的因子であるか友沠めるに は，なお今後の検討を必要とする。

\section{3. 考察}

\section{$3.1 \mathrm{Ni}$ 酸化膜の生成に対する $\mathrm{Na}^{+}, \mathrm{K}^{+}$の影響につ いて}

$\mathrm{NiO} の$ ようなきわめて抵抗の高い酸化物を母体にし て抵抗の低い酸化物半導体を得るために注，一般に金属 イオンか潩なった原子価で同等の格子点に存在する必要 がある，その1つの方法としては格子欠陌の生成によっ て母結晶队の金属イオンの原子価力湾化する場合と，異 なった原子価の他の金属イオンで結晶内の金属イオン の格子点を置換し，その原子価を変化させる場合とがあ る7. 後者はいわ心る原子価制御による半導体であって， 本実験の $\mathrm{Ni}(\mathrm{Li})$ 酸化膜はこれに相当する。原子価制御 老行ないうる添加金属イオンの条件の1つとして，母結 晶の金属イオンとそのイオン半径がほとんど等しいこと 在要とする．今，本実験の Ni 酸化物の場台の添加1 オンとしては 1 洒の陽イオンでイオン半径が 0.78 Ả 近いものである必要がある。 Li の原子婳は常に 1 䛧で イオン半往は $\mathrm{Ni}^{2+}$ 任とんぞ等しく $0.78 \AA^{*}$ である。ま た Li の第 2 イオン化ェネルギは $73.5 \mathrm{eV}$ で $\mathrm{Ni} の$ 第 3 イオン化エネルギの $35 \mathrm{eV}$ より大きい7．したがって本 実験の場合のような金属 $\mathrm{Ni}$ を $\mathrm{Li}^{+}$の存在のもとに酸化 すれば,生成する Ni 酸化膜中に Li が固溶してきわめて 導電性のよい,また格子欠陷の少ない緻密な $\mathrm{Ni}(\mathrm{Li})$ 酸化

* Goldschmidt によるイオン半径 


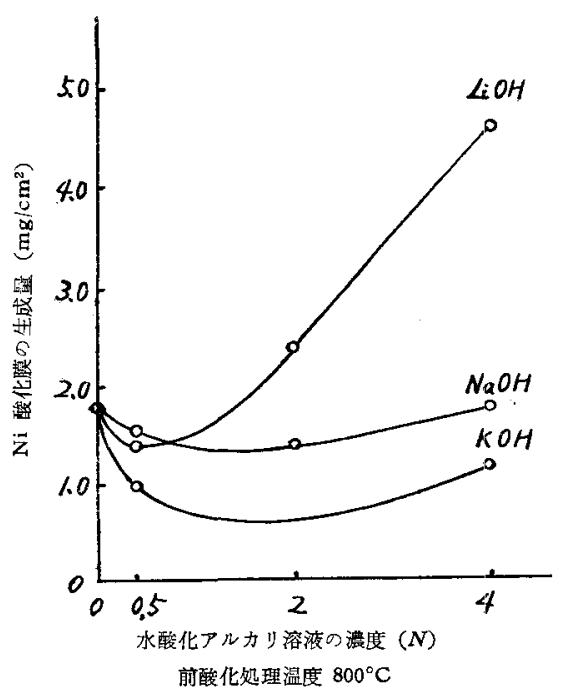

図 $9 \mathrm{Ni}$ 酸化膜の生成に及汇す $\mathrm{Na}^{+}, \mathrm{K}^{+}$の影響

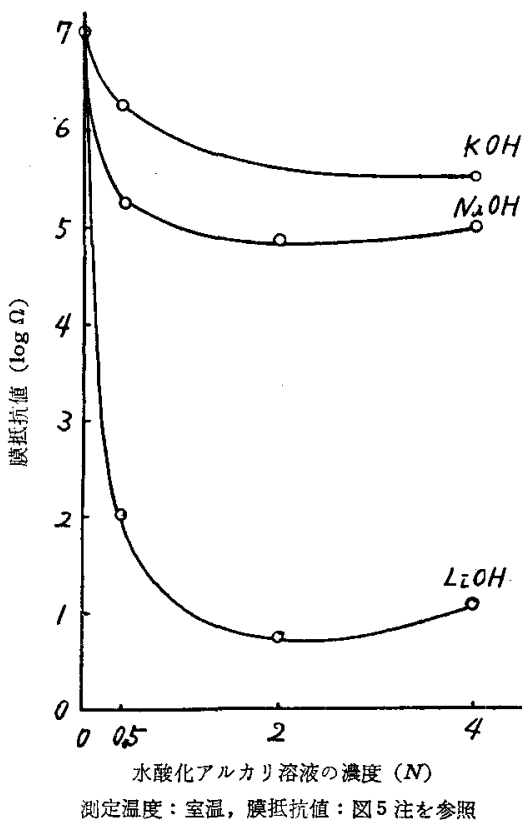

図 $10 \mathrm{NaOH}, \mathrm{KOH}$ による前酸化処理により 生成した $\mathrm{Ni}$ 酸化膜の抵抗

膜芫生成したのであろう， $\mathrm{Li}^{+}$がアルカリ金属イオンで あるから LiOH の代わりに同じ $1 \mathrm{a}$ 族の $\mathrm{NaOH}, \mathrm{KOH}$ の添加によっても尊電性のよい Ni 酸化膜る得るのでは ないかと単純に考えられるが，前述の原子価制御の理論 からすれば $\mathrm{Na}^{+}, \mathrm{K}^{+} の$ オン半径が $0.98,1.33 \AA^{*}$ と，
$\mathrm{Ni}^{2+}$ のイオン半径よりもかなり大きいので, $\mathrm{Li}^{+}$の場合 のように導電性のよい酸化膜を生成することは，困難で あろうと思われる。この点老実験的に明確にするために $\mathrm{LiOH}$ 溶液と大体当量の $\mathrm{NaOH}, \mathrm{KOH}$ 溶液を調製し, 同様な方法によって $800^{\circ} \mathrm{C}$ で加熱酸化した。その結果は 図 9, 図 10 に示すよらに酸化膜の生成量が少ないにも

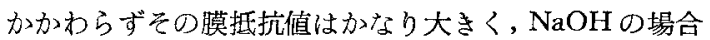
約 $10^{5} \Omega, \mathrm{KOH}$ の場合には約 $10^{6} \Omega$ であった，ての事 実は本実験の $\mathrm{Ni}(\mathrm{Li})$ 酸化膜の生成に関して原子価制御 の理論を適用して考察したことが正しいととな示すすの であるう。

\section{2 ニッケル電極の前酸化処理条件について}

Bacon らによれば， $\mathrm{O}_{2}$ ガスの共存する $\mathrm{KOH}$ 溶液 中, 膏温 $\left(200 \sim 300^{\circ} \mathrm{C}\right)$, 高生 $(50 \sim 60 \mathrm{~atm})$ の条件の下 で行なった金属 Ni 板の窗食試験において，あらかじめ 前酸化观理した試料 $\mathrm{Ni}$ 板注顕著な防食作用を示し，作 珵温度 $200^{\circ} \mathrm{C}$ では約 $1 \mathrm{mg} / \mathrm{cm}^{2}$ の $\mathrm{Ni}(\mathrm{Li})$ 酸化膜生成

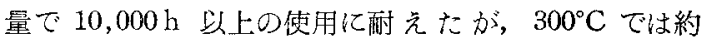
$2 \mathrm{mg} / \mathrm{cm}^{2}$ の $\mathrm{Ni}(\mathrm{Li})$ 酸化膜を必要とするとのことであ る.

これらの結果と本実験の結果から $\mathrm{Ni}$ 電極の前酸化処 理の最適条件について考察すると，

（1）浸せき用 $\mathrm{LiOH}$ について導電性 $\mathrm{Ni}(\mathrm{Li})$ 酸 化膜を得るためには 5〜10\%の溶液に浸せきすべきであ 3.

（2）加熱処理温度については $5 \% \mathrm{LiOH}$ に浸せき した場合には $700 \sim 800^{\circ} \mathrm{C}, 10 \%$ の場合には $650 \sim 700^{\circ} \mathrm{C}$ に空気中で $1 \mathrm{~h}$ 加熱すべきである。すなわち $600^{\circ} \mathrm{C}$ の加 熱では窗食变防ぐに十分な $\mathrm{Ni}(\mathrm{Li})$ 酸化膜を生成するこ とができずまた $10 \% \mathrm{LiOH}$ に浸せきし， $800^{\circ} \mathrm{C}$ の前酸 化処理では $\mathrm{Ni}(\mathrm{Li})$ 酸化膜生成が進行し過ぎもろくな り不適当である。一方 $5 \%$ より薄い $\mathrm{LiOH}$ 溶液では $\mathrm{Li}$ の含有率が柇さくなり十分な導電性を与えにくくなる。

(昭 $36-5-17$ 受理)

\section{文献}

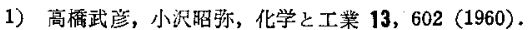

K.I. Rapp, "Proceeding 12 th Annual Battery Research and Development Conference" p. 8 (1958).

F.T. Bacon, British Pat. 667, 298 (1952), 725,661 (1955).

2) G.T. Young, "Fuel Cells" p. 51 (1960).

3) Y. Iida, J. Am. Cera. Soc. 43, 117, 171 (1960).

Y. Iida, S. Ozaki, K. Shimada, Bull. Chem. Soc. Japan 33, $656(1960)$.

4) 日化編，化学便筧 p. 593 (1958) 丸善.

5）竹內富久雄，大西 寞，松前鼎一，名工技試報告 6,719 (1957) ,

6) 日化編, 実験化学講座 10 巻 p. 159 (1957)

7) E.J.W. Verway et al., Philip Res. Rep. 5, 173 (1950). 